The writing sample below is a chapter I wrote for an edited collection:

'Celticism and the Four Nations in the Long Nineteenth Century', in N. Lloyd-Jones and M. Scull (eds.), Four Nations Approaches to Modern 'British' History: A (Dis-) United Kingdom? (Palgrave Macmillan, London, 2018), pp. 135-59.

\title{
Celticism and the Four Nations in the Long Nineteenth Century*
}

\section{Ian B. Stewart}

On 10 January 1828, the Caledonian Mercury published a scathing letter to the editor titled 'Celtic Blarney'. The author was incensed that the paper had printed a report of the Anniversary Dinner of the Highland Club of Scotland, and denigrated the account as 'doleful trash...the most admirable and unique compound of nonsense, blarney, and humbug that I ever remember to have read...flummery which would sconner a Hottentot'. The correspondent also impugned the editor using two of the most classic foils in British History, the Celts and the French - '...though by birth a Lowlander, you are almost as thoroughly inoculated with the rabies Celtica as the veritable sansculloterie of the Mountains' - before signing off as 'A GENUINE UNADULTERATED GOTH'. ${ }^{1}$ Reflecting on the turbulence of the European revolutions twenty years later, The Economist used a similar trick, exclaiming 'Thank God! We are Saxons!... Flanked by the savage Celt on one side, and the flighty Gaul on the other...The Frenchman is a civilised Celt. The Irishman a Barbaric Gaul'. ${ }^{2}$

These are familiar themes: English exceptionalism, Celtic marginalisation, and the spectre of the French. In historiography, Anglo-French connections and relations are perpetually re-assessed, while English constitutional history was purged of whiggishness long ago, but the Celt-versus-Saxon dichotomy remains alive and well. ${ }^{3}$

\footnotetext{
* I would like to thank the editors and anonymous reviewers, as well as Paul Readman and the Modern British History Reading Group at King's College London for comments on a draft of this chapter.

${ }^{1}$ Caledonian Mercury, 10 January 1828.

2 'The Saxon, The Celt, and The Gaul', Economist, 29 April 1848.

${ }^{3}$ For the Anglo-French relationship see, e.g., R. Gibson (2004) Best of Enemies: Anglo-French Relations Since the Norman Conquest (Exeter); R. and I. Tombs (2006) That Sweet Enemy: The French and the British from the Sun King to the Present (London); C. Charle, J. Vincent and J. Winter (eds.) (2007) Anglo-French attitudes: Comparisons and transfers between English and French intellectuals since the eighteenth century (Manchester). For the assault on whiggism see H. Butterfield (1931) The Whig Interpretation of History (London); L. Namier (1929) The Structure of Politics at the Accession of George III (London). For studies that assess Celticism see, e.g., M.G.H. Pittock (1999) Celtic Identity and the British Image (Manchester); N. Davies (1999) The Isles: A History (London); B. Nelson (2012) Irish Nationalists and the Making of the Irish Race (Princeton) relies on the Celt-Saxon framework of the once seminal work of L.P. Curtis Jr. (1968) Anglo-Saxons and Celts: A Study of
} 
Although racial essentialism is no longer a factor in history writing, the Celts are still employed as a simplistic 'other'. ${ }^{4}$ This has happened in part because terminological confusion has always existed in relation to the word 'Celt' and its derivatives, which are as variable and vague as they are ubiquitous. 'Celtic' can be used to refer to a branch of the Indo-European language family, to describe a 'race' of people, or as shorthand for nations meaning 'not England'. In this chapter I follow Joep Leerssen's definition of 'Celticism' as the study, not of the Celtic peoples themselves, but of the "reputation and...meanings and connotations ascribed to the word "Celtic" in different historical periods. ${ }^{5}$ However, while there has always been a certain plasticity to the 'Celts', there are clearly discernible meanings employed and understood in different historical eras. Therefore, whatever convenience is derived from the tendency towards blanket use of the word 'Celtic' to refer to the non-English nations of the Isles is more than negated by its distortion of the past. For example, Michael Hechter's use of 'Celtic Fringe' to describe the territory subjected to creeping English hegemony from the sixteenth century has been influential, but the phrase 'Celtic Fringe' itself is dateable to the $1890 \mathrm{~s} .{ }^{6}$ Here linguistic convenience, reflecting a model that is too simplistic, glosses over the vastly different histories of each of the nations vis-à-vis not only England, but each other. As this chapter will show, there was no real sense of Celtic kinship amongst any of the different nations of the Isles until the middle of the nineteenth century; on the contrary, throughout the eighteenth century they were more likely to compete amongst one another for the claim to be the purest descendants of the ancient Celts, rather than to unite based on familial sentiment.

'Four nations' history, which has sought to redress the balance of emphasis among England and the other nations of the Isles, ${ }^{7}$ has done little to question the received

Anglo-Irish Prejudice in Victorian England (Bridgeport, Conn.); L.P. Curtis Jr. (1971) Apes and angels: the Irishman in Victorian caricature (Washington, D.C.).

${ }^{4}$ Colin Kidd (2008), Union and Unionisms : Political Thought in Scotland, 1500-2000 (Cambridge), pp. 170-2, identifies Gordon Donaldson (1913-1993) as the last of the Scottish Teutonist tradition.

5 J. Leerssen (1996) 'Celticism', in T. Brown (ed.) Celticism (Amsterdam), p. 3.

${ }^{6}$ Michael Hechter (1975) Internal Colonialism: The Celtic Fringe in British National Development, 1536-1966 (London); 'Celtic fringe', in OED Online. Oxford University Press, June 2016, accessed 2 August 2016.

${ }^{7}$ This aim is different from J.G.A. Pocock's original intention of spawning a 'New British History' that turned away from Europe and towards the commonwealth, see J.G.A. Pocock (1975) 'British History: A Plea for a New Subject', Journal of Modern History, XLVII, 601-21. For a recent assessment, see R. Bourke (2010) 'Pocock and the Presuppositions of the New British History,' Historical Journal, LII, 747-770. 
narratives around ideas of the Celt. This is unsurprising given the initial emphasis of the 'New British History' on explaining the formation of the British state from the 'Three Kingdoms', unavoidably tending towards an Anglocentric teleology already prevalent in British historiography. ${ }^{8}$ As David Cannadine has pointed out, even though the nineteenth century saw the most complete integration of the British state, nation and empire, English whig history predominated until the Second World War: ${ }^{9}$ British successes were English triumphs. ${ }^{10}$ After the war, non-English historiographies increasingly reconsidered their own national pasts, vastly understudied in comparison to that of the English. Irish, Scottish and Welsh historiographies have all been concerned to a considerable extent with their own 'national question', and each now possesses its own extensive historical literature relating to issues of national identity and nation building. An unintended consequence has been a 'silo effect', wherein these historiographies exist largely independent of one another. While seminal works on Britain and Britishness certainly exist, ${ }^{11}$ they do not add up to an integrated British History. 'Four nations' history, overlapping with the emergent transnational approaches in the last several decades, now seeks to link up the separate lines of national histories and identify hitherto overlooked angles in the modern period. But the nations have been and are joined by far more than just the political arrangements of the state superstructure, and shared ideas and culture have been fruitful areas of investigation. ${ }^{12}$ It is therefore the aim of this chapter to examine and reassess Celtic ideas and their cultural outlets, revealing the ways in which they underpinned integrative concepts and processes in the four nations of the British Isles during the 'long nineteenth century'.

\footnotetext{
${ }^{8}$ See, e.g., A. Grant \& K.J. Stringer (eds.) (1995) Uniting the Kingdoms? The Making of British History (London); R.G. Asch (ed.) (1993) Three Nations - A Common History? England, Scotland, Ireland and British History, c.1600-1920 (Bochum); G. Burgess (ed.)(1999) The New British History: Founding a Modern State, 1603-1715 (London); B. Bradshaw \& P. Roberts (eds.)(1998) British Consciousness and Identity. The Making of Britain, 1533-1707 (Cambridge); B. Bradshaw \& J. Morrill (eds.) (1996) The British Problem, c.1534-1707. State Formation in the Atlantic Archipelago (Basingstoke); B. Crick (ed.) (1991) National Identities: The Constitution of the United Kingdom (Oxford).

${ }^{9}$ D. Cannadine (1995) 'British History as a "new subject". Politics, perspectives and prospects,' in Grant \& Stringer, Uniting the Kingdoms?, pp. 12-28.

${ }^{10}$ See, e.g., R. Colls (1998) 'The Constitution of the English', History Workshop Journal, XLVIII, $97-$ 127.

${ }^{11}$ L. Colley (1992) Britons: Forging the Nation, 1707-1837 (New Haven); K. Robbins (1988) Nineteenth-Century Britain: Integration and Diversity (Oxford); P. Ward (2004) Britishness since 1870 (London).

${ }^{12}$ For an especially novel take see C. Harvie (2008) A Floating Commonwealth: Politics, Culture and Technology on Britain's Atlantic Coast, 1860-1930 (Oxford).
} 
Two major trends have emerged in treating Celticism in the Isles. The first has been employed in the social sciences, where a 'core-periphery' model is used to explain the creation of the Celts by a metropolitan centre. ${ }^{13}$ This approach tends to treat all nonEnglish nations as 'Celtic', thereby ignoring intra-national cleavages and the variety of ideas around the Celts. The second tendency, seen more in historical and literary studies, is to examine how Celticism has factored into 'Britishness', or rather how Celtic ideas have underpinned certain national - and almost always separatist identities. ${ }^{14}$ Though Celticism did come to buttress national ideas and identities to differing extents in Ireland, Scotland and Wales, not to mention Cornwall, the Isle of Man or Brittany, this did not occur in most cases until the mid-eighteenth century, and did not immediately imply separatist aims. ${ }^{15}$ It was near universally agreed that the ancient Celtae described by Caesar had at one time populated the Isles; ${ }^{16}$ the question was to what extent the later Anglo-Saxon, Viking and Norman invasions had supplanted them, if at all. The importance of the Celtic past waned in England as it waxed in the other nations, but even well into the nineteenth century Celtic ideas were not inherently separatist, though they did come to underpin movements for increased autonomy and, increasingly, versions of independence in their respective nations. Eventually many modern Celts of the various nations recognised their racial kinship, leading to the emergence of Pan-Celticism at the end of the nineteenth century, institutionalised in The Celtic Association, which sought to connect all of the Celtic nations and form an extra-Anglo polity, thereby inverting the idea of Great Britain and seeking to make England peripheral to the Celtic nations.

Examining Celticism in the four nations holistically reveals overlooked trends that cut against the historiographical grain. For example, Celtic descent was drawn upon in different nations at different times, and Celticism was not simply reducible to nonEnglishness. There were prominent English scholars in the eighteenth and nineteenth centuries claiming the Celtic mantle for the English. Undoubtedly, anti-Celtic racism

\footnotetext{
${ }^{13}$ Hechter, Internal Colonialism; M. Chapman (1993) The Celts: The Construction of a Myth (Basingstoke).

${ }^{14}$ See, e.g., Pittock, Celtic Identity; Davies, The Isles.

${ }^{15}$ I do not use 'identity' here to imply that all those in the so-called 'Celtic nations' recognised themselves to be Celtic, but that a variety of national images arose during this century - from within and without the nations themselves - which relied on the idea of Celtic descent.

${ }^{16}$ No classical writer explicitly described the aboriginal Britons as 'Celtae', though by the early modern period it was surmised they were the same, see, e.g., D. Hume (1754-61: 1767) The History of England, from the Invasion of Julius Caesar to The Revolution in 1688, $2^{\text {nd }}$ edn (8 vols., London), I, p. 2.
} 
existed in a variety of quarters; for example, in the eighteenth-century antiquarianism of John Pinkerton (1758-1826), the Victorian anthropology of Robert Knox (17931862) and his circle, or the constitutionalist history ring around E.A. Freeman (18231892), and frequently in the popular press. ${ }^{17}$ But many, like J.S. Mill (1806-1873), played down the importance of race in the Celtic context or, like Matthew Arnold (1822-1888), flipped it on its head, arguing that racial science suggested the British were actually a mixed-blood Anglo-Celtic hybrid. This chapter therefore hopes to offer some suggestive examples of a topic that demands extended and detailed study.

Celticism was a point of contention amongst the four nations in the early modern period. The Isles were far from integrated culturally, let alone politically or socially, during the early modern period, as open conflict reinforced long-running prejudices among the three kingdoms (and four nations). Ethnicity was based on national descent, which was crucial because the past functioned as authority: an esteemed ancestral lineage meant more prestige in the present. Though competing versions of constitutionalism accorded differing degrees of importance to ethnicity, with AngloSaxonism gradually ascendant, by and large the Celts were not depicted negatively. ${ }^{18}$ On the contrary, Celtic ideas could be seen as unifying rather than divisive, and one strand of Gothicism held the Celts to be part of the same northern European people as the Angles, Saxons, Jutes, and Teutons, thus preserving the same ancient freedoms as the Anglo-Saxons. ${ }^{19}$ This Celto-Gothic interpretation peaked in the middle of the eighteenth century, ${ }^{20}$ but collapsed shortly thereafter, albeit surviving on the continent into the nineteenth century. Yet nineteenth century Celtic ideas relied on the eighteenth century ideas and myths of Celtic national descent explored in this section; recognition of the latter is imperative to a correct understanding of the former.

\footnotetext{
${ }^{17}$ P. O'Flaherty (2015) Scotland's Pariah: The Life and Work of John Pinkerton, 1758-1826 (Toronto); G. W. Stocking Jr. (1987) Victorian Anthropology (New York), pp. 64-5; C. J. W. Parker (1981) 'The Failure of Liberal Racialism: The Racial Ideas of E. A. Freeman,' Historical Journal, XXIV, 825-46.

${ }^{18}$ See C. Kidd (1999) British Identities before Nationalism: Ethnicity and Nationhood in the Atlantic World, 1600-1800 (Cambridge), esp. ch. 4.

${ }^{19}$ R.J. Smith (1987) The Gothic Bequest: Medieval institutions in British thought, 1688-1863 (Cambridge), pp. 61-2, p. 112; Kidd, British Identities.

${ }^{20}$ S. Kliger (1952) The Goths in England: A Study in Seventeenth and Eighteenth Century Thought (Cambridge, MA.), pp. 84-5.
} 
The history of the British Isles was firmly structured within a European framework, to which the Celts were central. The third edition of the Encyclopaedia Britannica, published in 1797, lists the 'CELTÆ, or CELTES' as 'an ancient nation, by which most of the countries of Europe are thought to have been peopled'. ${ }^{21}$ The only written records of the ancient Celts were descriptions by classical writers, which left early modern scholars unsure whether there had been a contiguous Celtic polity or society. However, it was generally agreed there had been a single Celtic language. While Christian theology viewed Hebrew as the original language of humanity, some scholars began to challenge this idea during the seventeenth century, either equating Hebrew with Celtic or substituting Celtic in its place. ${ }^{22}$ Because the language used by the ancient Celts was unknown and unwritten, ${ }^{23}$ any nation could claim to have best preserved it, and German, French, Swedish, Dutch, Welsh, Scottish, Irish and English scholars all squabbled over the Celtic mantle, until the Indo-European language paradigm pioneered by William Jones (1746-1794) at the end of the eighteenth century eventually offered solutions to the question of the 'Original language'. ${ }^{24}$

Britain was very much a part of this European intellectual power struggle. The Isles were thought to have been populated by the Celts, a common thread in the humanism of figures like Jean Bodin (1530-1596), Philippus Cluverius (1580-1622), George Buchanan (1506-1582) and William Camden (1551-1623), though Ireland's provenance was contentious. Cluverius stated the peopling of Ireland was uncertain, 'but that they were Celte, as the other Britaines, [sic] is probable', an interpretation that strengthened over the seventeenth and eighteenth centuries. ${ }^{25}$ However, Cluverius argued that the German language was closest to that of the ancient Celts. Terminological confusion reigned, and because the Celts were thought to have occupied most of Europe, they could be claimed as ancestors by any of these nations.

\footnotetext{
21 'Celtae' (1797) in Encyclopaedia Britannica; or, a Dictionary of Arts, Sciences, and Miscellaneous Literature, $3^{\text {rd }}$ edn (18 vols., Edinburgh), IV, p. 283.

${ }^{22}$ T. Van Hal (2014) 'One continent, one language? Europa Celtica and its language in Philippus Cluverius' Germania Antiqua (1616) and beyond', European Review of History: revue européenne d'histoire, XXI, 889-907.

${ }^{23}$ Aside from Ogam inscriptions, though these date from the fifth and sixth centuries A.D. and were not first researched until 1785, at which time Celtic prestige was in full decline [K. Forsyth (2006) 'ogam inscriptions and primitive Irish', in J.T. Koch, Celtic Culture: A Historical Encyclopaedia (5 vols., Santa Barbara, CA.), IV, pp. 1390-93].

${ }^{24}$ See J. Turner (2014) Philology: The Forgotten Origins of the Modern Humanities (Princeton), pp. 98-9.

${ }^{25}$ P. Cluverius (1657) An Introduction into Geography, both Ancient and Moderne, comprised in sixe books (Oxford), p. 109.
} 
Far from the modern idea of a 'Celtic fringe' on the Atlantic coast of Europe, the entire continent could be referred to as the relic of an ancient Europa Celtica, and it was not until the turn of the eighteenth century that the geographical specificity of the Celts, with their dialects and cultural vestiges, began to be confined to the British Isles and Brittany. ${ }^{26}$

Several scholars, aware of each other's work and corresponding intermittently, shifted the debate. The Breton Abbé Paul-Yves Pezron (1639-1706) claimed that the Celts were the descendants of Noah's grandson Gomer, whose language was preserved most completely in Breton and Welsh: 'The people who are in Brittany... and also those who live over the sea, I mean Wales...these are those who have the honour of having preserved the language of the descendants of Gomer... ${ }^{27}$ Translated into English in 1706, the work proved enormously influential and was re-issued throughout the eighteenth and nineteenth centuries. In 1707 Edward Lhwyd (16601709), the Welsh keeper of the Ashmolean Museum and an admirer of Pezron, published the first volume of his Archaeologia Britannica, a rigorous work on the 'Ancientest Languages of Britain and Ireland' that painstakingly detailed the affinity among the Welsh, Cornish, Breton, Irish, and Scots Gaelic languages. The work is now seen as the first major development in Celtic linguistics, but Lhwyd's aim was primarily to draw 'a Clear Notion of the First Planters of the Three Kingdoms' ${ }^{28}$ Lhwyd's emphasis here points to the importance attached to the question of which nation had the strongest claim to be the original inhabitants of the islands. It was an academic truism that the different nations were descended from the Celts, what really mattered was being the purest descendants of the first Britons, a claim to which the Welsh fiercely clung, arguing that the modern British constitution was inherited from their original Briton ancestors rather than the Saxons. ${ }^{29}$ Although a Welsh patriot, Lhwyd declared Irish to be elder than Welsh and Breton, a hypothesis supported by the enormously influential German polymath G.W. Leibniz (1646-1716), who cited

\footnotetext{
${ }^{26}$ Van Hal, 'One continent, one language?'.

${ }^{27}$ P. Pezron (1703) Antiquité de la Nation \& de la Langue des Celtes, autrement appellez Gaulois (Paris), 'Preface', np. '...les Peuples qui sont dans la Petite Bretagne...\& ceux encore qui habitant audelà de la mer, j'entens au païs de Galles...Ce sont eux qui ont l'honneur d'avoir conservé la Langue des descendans de Gomer...' (translations my own).

${ }^{28}$ E. Lhwyd (1707) Archaeologia Britannica, Giving some account Additional to what has been hitherto Publish'd, of the Languages, Histoires and Customs Of the Original Inhabitants of Great Britain: From Collections and Observations in Travels through Wales, Cornwal, Bas-Bretagne, Ireland and Scotland (Oxford), I, Glossography, 'The Preface', np.

${ }^{29}$ P. Morgan (1981) The Eighteenth Century Renaissance (Llandybïe).
} 
Lhwyd and refuted Pezron explicitly in his posthumously published Collectanea Etymologica (1717). Finally, the Irish deist John Toland (1670-1722), who claimed to have given Lhwyd the idea to examine the languages comparatively, ${ }^{30}$ outlined in 1718-1719 three letters to the Irish peer Robert Molesworth (1656-1725) 'A Specimen of the Critical History of the Celtic Religion and Learning'. Toland also declared Irish to be more ancient than Welsh, crucially connecting the language to the Druids and disentangling it from Gothic: 'the Celtic and the Gothic [languages], which have been often taken for each other, are as different as Latin and Arabic'. ${ }^{31}$ These various works further rooted the Celts to the Isles; however, scholars disagreed - largely but not solely due to patriotism - over the antiquity of the different Celtic 'dialects' and traditions, arguing over which nation had the most authentic claim to be the closest descendants of the original Celtic inhabitants.

Eighteenth-century antiquarianism thus had several related Celtic strands to draw upon, which were mixed according to the convictions and biases of the author. Henry Rowlands (1655-1723), an Anglesey vicar and friend of Lhwyd, combined his ideas with those of Pezron - 'that great light of our British antiquities' - to argue that Anglesey (Mona) was the home of the Druids and that the language called 'Celtic or British...was undoubtedly one of the primary vocal modes and expressions of mankind after the dispersion at Babel'. He provided language tables comparing Welsh and Hebrew to prove the assertion. ${ }^{32}$ The English antiquary Francis Wise (1695-1767) drew on Pezron, Lhwyd and Toland, directly suggesting Celtic - preserved most purely in Irish - could be called 'the Universal language of the post-diluvian world' and was safely protected from the Gothic in the 'corners, and hiding places' of western Europe. ${ }^{33}$ Wise's friend, the English archaeological pioneer William Stukeley (1687-1765), took a similar line, drawing heavily on Toland and the antiquary John Aubrey (1626-1697) in arguing that monuments like Stonehenge and Avebury were built by Celtic Druids. But Stukeley, an Anglican clergyman, fashioned his own ideas of the Druidical philosophy into a defence of Trinitarianism - the idea that God exists

\footnotetext{
${ }^{30}$ J. Leerssen (1986) Mere Irish and Fior-Ghael. Studies in the Idea of Irish Nationality, Its Development and Literary Expression Prior to the Nineteenth Century (Amsterdam), pp. 288-9.

${ }^{31}$ J. Toland (1726) 'A Specimen of the Critical History of the Celtic Religion and Learning', in $A$ Collection of Several Pieces of Mr. John Toland, (2 vols., London), I, p. 7.

${ }^{32}$ H. Rowlands (1723) Mona Antiqua Restaurata (Dublin), p. 33, p. 295.

${ }^{33}$ F. Wise (1758) Some Enquiries concerning the First Inhabitants, Language, Religion, Learning and Letters of Europe (Oxford), pp. 29-32.
} 
as Father, Son and Holy Spirit - rejecting the freethinking deism of figures like Toland. ${ }^{34}$ Celtic ideas and origins could thus be the vehicle in which other, more immediate, arguments were advanced. No single interpretation was cogent enough to hold the field, but the broad lines of argument were re-hashed over the following century, and were an important part of antiquarian and historical studies of the Isles.

The centrality of Celtic ideas to the history of the British Isles in the eighteenthcentury is a stark contrast to the denigration of the Celts in favour of the Saxons by some authors during the nineteenth century. Stukeley privileged the Celts, arguing that 'Britania' was a Celtic word from the ancient Britons, who by the 'Ungratful Saxons [sic]' were forced through 'barbarous violence and savage masacr [sic]...to retire into the baron and mountainous parts of Cumberland, Cornwal [sic] and Wales...' 35 David Hume (1711-1776), an unapologetic Lowland Saxonist, nevertheless acknowledged the Celtae as the first Britons and asserted Celtic 'governments, though monarchical, were free, as well as those of all the Celtic nations' ${ }^{36}$ The etymologist John Cleland (1709-1789), author of Memoirs of a Woman of Pleasure, or 'Fanny Hill', maintained English to be closest to the ancient Celtic language. ${ }^{37}$ James MacPherson (1736-1796) - briefly the doyen of British antiquarians on the back of Ossian's popularity - contended not only that the Celtae were the original inhabitants of Europe, but that their name derived from the appellation 'Gaël', synonymous with Scottish Highlanders, who first peopled the Isles, rather than the Britons (Welsh). ${ }^{38}$ Ethnicity clearly had some import, but by and large the fact that power in the Isles was increasingly consolidated by a nation purporting itself as Anglo-Saxon did not preclude Celtic dignity or a share of historical significance. The shrill tone and exclusionism of high racialism were a long way away.

MacPherson embodied the zenith of enthusiasm for the Celtic past - retrospectively labelled 'Celtomania' in the nineteenth century - and both Ossian and his $A n$

\footnotetext{
${ }^{34}$ S. Piggott (1950) William Stukeley: An Eighteenth-Century Antiquary (Oxford), p. 34, p. 126.

${ }^{35}$ W. Stukeley, 'Origines Britannicae', in Society of Antiquaries Library, William Stukeley Papers, MS 793.

${ }^{36}$ Hume, History of England, I, p. 3.

${ }^{37}$ J. Cleland (1766) The Way to Things by Words, and To Words by Things; being a Sketch of An Attempt at the Retrieval of the Ancient Celtic, or, Primitive Language of Europe (London).

${ }^{38}$ J. MacPherson (1771) An Introduction into the History of Great Britain and Ireland (London), p. 6, p. 9 , p. 24.
} 
Introduction to the History of Great Britain and Ireland (1771) were increasingly challenged in the last three decades of the eighteenth century, creating space for the acceleration and ascendance of the Anglo-Saxon paradigm. The first and most devastating assault on Celtic ideas came from the English Anglican Bishop Thomas Percy (1729-1811), who divided Europe between the Celts - Gauls, Britons and Irish - and the Goths or Teutons - Germans, Belgians, Saxons and Scandinavians. ${ }^{39}$ Language tables and comparisons between Druidism and the Gothic religion of Odin demonstrated that the 'Teutonic and Celtic Nations were Ab origine two distinct people'. ${ }^{40}$ Percy consulted a Welshman named Evan Evans (1731-1789) who, irked by MacPherson and his Scottish chauvinism, guided Percy through some of the relevant literature, declaring "no nation in Europe possess greater remains of ancient and genuine pieces [of poetry]...than the Welsh'. ${ }^{41}$ Percy - finding it 'pleasant to have MacPherson attacked by a "North Briton" 42 - proved an inspiration and cautious mentor to the vehemently anti-Celtic lowlander John Pinkerton, who sneered that the eighteenth century could be 'called the Celtic Century, for all Europe has been inundated with nonsense about the Celts'. ${ }^{43}$ Pinkerton's Dissertation on the Scythes painted the Scythes as progenitors of most European nations - and direct ancestors of the Anglo-Saxons - who had conquered the Celts and pushed them to the fringes of western Europe. Writing around the same time as Pinkerton, Sharon Turner (1768-1847) - also influenced by Percy - produced the first modern Saxon history of England, declaring 'Our language, our government, and our laws, display our Gothic ancestors in every part' ${ }^{44}$ The Celts, already pushed to the geo-political margins of the Isles were now being pushed to the intellectual and ideological margins as well.

Celtic importance in English antiquarian thought plummeted as the eighteenth century ended, though it remained stable in the other nations of the Isles. However, in the context of the eighteenth-century rise of particular national ideas, the 'Celtic nations' did not accord much importance to their kinship - as evidenced by writers like

\footnotetext{
${ }^{39}$ T. Percy (1770) 'translator's preface', in Paul-Henri Mallet, Northern Antiquities (2 vols., London), I, p. vii.

${ }^{40}$ Percy, 'translator's preface', i.

${ }^{41}$ E. Evans (1764) Some Specimens of the Poetry of the Ancient Welsh Bards (Montgomery), p. 7.

${ }^{42}$ Thomas Percy to Rev. Dr Thomas Campbell, 6 October 1787, RP 1766, British Library.

${ }^{43}$ J. Pinkerton (1787) A Dissertation on the Origins and Progress of the Scythians Or Goths: Being an Introduction to the Ancient and Modern History of Europe (London), p. 123.

${ }^{44} \mathrm{~S}$. Turner (1807) The history of the Anglo-Saxons, $2^{\text {nd }}$ edn (2 vols., London), I, pp. 27-8, cited in Kidd, British Identities, p. 98.
} 
MacPherson and Evans. The competition among antiquarians from each of the four nations reveals that Celticism was a source of conflict amongst Welsh, Scottish and Irish scholars in the eighteenth century, where Ossian proved the flashpoint; there was no sense of a shared identity of marginalisation or oppression. ${ }^{45}$ It can be argued that Saxonist scholars, even by denigrating the Celts, actually helped to connect ideas of the different Celtic nations by treating them monolithically. Nevertheless, as English power and Saxon prejudice increased into the nineteenth century, the other three nations eventually had recourse to ideas that linked them, ultimately setting the stage for the emergence of pan-Celticism.

Ideas of a Celtic 'race' became popular at the beginning of the nineteenth century, as developments in the 'racial sciences' of anthropology, ethnology, and philology catalysed racial thinking and the classification of peoples. ${ }^{46}$ Nations and races were compared throughout the early modern period but these categories had more to do with ideas of genealogy and descent and, as Colin Kidd has argued, the biblical framework in which scholarship operated stressed the descent of man from one common source (monogenesis) and precluded separating mankind into distinct categories of origin (polygenesis). ${ }^{47}$ Racial typologies and rankings emerged with the 'secularisation of knowledge' - the decoupling of scholarship from theology - that occurred with Enlightenment. However, at the same time, the Indo-European linguistic paradigm suggested the common root of most European languages, including those in the Celtic branch, pointing to familial links of Indo-European peoples. Ironically, while philology pointed to common kinship of Celts and Saxons, a few outspoken ethnologists and much of the popular press kept them divided. Against the background of increasing national consciousness, the ethnic makeup of nations mattered less in proving a particular descent than it did for more immediate

\footnotetext{
${ }^{45}$ Cf. Hechter, Internal Colonialism; Pittock, Celtick Identity.

${ }^{46}$ Stocking Jr., Victorian Anthropology, pp. 47-53; L. Poliakov, E. Howard (trans.) (1974) The Aryan Myth: A History of Racist and Nationalist Ideas in Europe (London); R. McMahon (2007) 'The Races of Europe: Anthropological Race Classification of Europeans, 1839-1939', (unpublished PhD Thesis, European University Institute, Florence).

${ }^{47}$ Kidd, British Identities; C. Kidd (2006) The Forging of Races: Race and Scripture in the Protestant Atlantic World, 1600-2000 (Cambridge).
} 
hard and fast national differences in the present $-\mathrm{a}$ frequent recourse of British politicians and the press in assessing the situation in Ireland in particular.

The nineteenth century political landscape of the United Kingdom, particularly the situation in Ireland and unsteady union of 1800, furnished the important backdrop for Celtic ideas in the nineteenth century. For the British ruling class, the 'otherness' of the Celtic race provided a ready-made excuse for Irish differences and the inability of the British to adequately govern the island, as outlined by the pioneering works of L.P. Curtis Jr. ${ }^{48}$ However, Curtis' approach to the English-Irish relationship as a dichotomy of Saxon vs. Celt has resulted in an equation of the two, tangling the wispier threads of the relations between Celts and Saxons in Britain, as opposed to the United Kingdom. These require gentle untying rather than forceful separation. Undoubtedly anti-Celtic prejudice existed in a variety of guises during the nineteenth century and the repugnance of Victorian racialism and 'Teutomania' linger heavily in historical memory, but this treatment has been too monolithic. The paradigms of understanding shifted, but Anglo-Celtic overlaps existed in the nineteenth century, just as they had in the eighteenth.

Ethnology was the key field for the developing racial ideas of Celt and Saxon. However, the dominant figure in British ethnology - James Cowles Prichard (17861848), a Bristol physician of Welsh parentage - protected the Celts in this scientific realm. Remembered most for his Researches into the Physical History of Man (1813), Prichard proved through philological comparison that the Celtic languages belonged to the Indo-European family in The Eastern Origins of the Celtic Nations (1831). But Prichard's primary motivation was religious rather than patriotic; raised a Quaker, his scholarship revitalised a Christian science of man that defended monogenesis from the onslaughts of polygenesis, which was advocated by Pinkerton but also occupied a strong foothold in France, where racial categories hardened under positivist influence. ${ }^{49}$ It was in Paris that the foremost British polygenist, Robert Knox, studied comparative anatomy before he became professor of Anatomy in Edinburgh. ${ }^{50} \mathrm{~A}$ racial determinist, Knox's theories resembled those of Joseph de Gobineau (1816-

\footnotetext{
${ }^{48}$ Curtis, Anglo-Saxons and Celts; Curtis, Apes and Angels.

${ }^{49}$ H.F. Augstein (1999) James Cowles Prichard's Anthropology: Remaking the Science of Man in Early Nineteenth-Century Britain (Amsterdam), p. xi, p. 4, p. 59; Stocking, Victorian Anthropology, pp. 25-30.

${ }^{50}$ Stocking, Victorian Anthropology, p. 64.
} 
1882) in contending that race-mixing caused the decay of civilisations and attacked Prichard, whom he placed among the 'well meaning, timid persons' who 'dreaded the question of race'. ${ }^{51}$ According to Knox, the biological inferiority of other races justified Britain's right to empire around the globe and more locally in Ireland. $\mathrm{He}$ also argued for the Saxon commonality of England and the Lowlands, which the Celts had never occupied: 'the Caledonian Celt of Scotland appears a race as distinct from the Lowland Saxon of the same country as any two races can possibly be..., ${ }^{52}$ The Celts were inferior in battle, proved by Celtic defeats at Culloden, the Boyne, and Waterloo. ${ }^{53}$

No doubt for the fervour of his unsavoury ideas, Knox stands out as a Victorian racist par excellence. But although he had followers, particularly those who formed the Anthropological Society of London in 1863, Knox was a provocateur and his extreme views are not representative. Treatment of race was normally more nuanced, even in scientific works. ${ }^{54}$ The English barrister and amateur ethnologist Luke Owen Pike (1835-1915) took issue with Knox and those who divided Britain between two races, arguing that the Celtic race still made up the majority of the English (and British) nation, despite repeated invasions. ${ }^{55}$ Pike pointed out the problems of identifying races of people through philology, arguing 'the partly Anglo-Saxon origin of the English language does not necessarily imply the Anglo-Saxon origin of the English people ${ }^{56}$ Other scholars - Thomas Price (1787-1848), Richard Garnett (1789-1850), Robert Latham (1812-1888), and Isaac Taylor (1787-1865) - challenged the racial supremacy of the Saxons on anthropological and linguistic bases. In 1862, John Beddoe (1826-1911) published his landmark study The Races of Britain, containing his famous 'index of negrescence', a scale measuring eye, hair and skin colour and

\footnotetext{
${ }^{51}$ Knox, Races, p. 13.

${ }^{52}$ R. Knox (1850) The Races of Man: A Fragment (Philadelphia), p. 18.

${ }^{53}$ Knox, Races, p. 19.

${ }^{54}$ Peter Mandler has convincingly argued this point both in relation to Knox and more generally, see P. Mandler (2004) 'The Problem with Cultural History', Cultural and Social History, I, pp. 100-3; P. Mandler (2006) The English National Character: The History of an Idea from Edmund Burke to Tony Blair (New Haven); Stocking, Victorian Anthropology, pp. 247-8. However, see Krisztina Fenyo (2000) Contempt, Sympathy and Romance: Lowland Perceptions of the Highlands and the Clearances During the Famine Years, 1845-1855 (East Linton), for the denigration of the Highlanders as grouped with the Irish by the Lowland press around the same time.

${ }^{55}$ L. Owen Pike (1866) The English and Their Origin. A Prologue to Authentic English History (London), p. 245.

${ }^{56}$ Pike, The English, p. 239.
} 
reducible to the equation: ' $\mathrm{D}+2 \mathrm{~N}-\mathrm{R}-\mathrm{F}=$ Index ${ }^{57}$ Britons became darker the further west one travelled, and Beddoe equated the Celts to the 'Negroid' type found in Africa. When the book was re-issued in 1885, Beddoe felt Saxonism to be in full decline: 'It is not very long since educated opinion considered the English and Lowland Scots an almost purely Teutonic people. Now the current runs so much the other way that I have had to take up the attitude of an apologist of the "Saxon" view' ${ }^{58}$ But Beddoe is not reducible to a Saxon chauvinist, the book having developed from a prize-winning essay submitted to the 1868 National Eisteddfod, which helped to fund its publication. ${ }^{59}$ Differences in race were seen to be matters of fact, and those who deemed themselves Celts were as interested in their distinctiveness as Anglo-Saxonists were, a consideration overlooked in the AngloCeltic dichotomy.

Racialism was not the exclusive preserve of science, and was more strident in popular discourse. For instance, the character Sidonia in Benjamin Disraeli's (1804-1881) novel Tancred (1847) reflected a prominent sentiment of the age when, musing on the success of English civilisation, he declared '... it is an affair of race. A Saxon race, protected by an insular position, has stamped its diligent and methodic character on the century...All is race, there is no other truth'. ${ }^{60}$ While Knox's broadsides against the Celts following the 1848 upheavals - the 'Celtic race could never comprehend the meaning of the word liberty ${ }^{\prime 61}$ - were echoed in places like The Economist (see p. 1), many denounced the notion that the Celtic race was inherently rotten. J.S. Mill defended the Irish, arguing that imputing difference to race was the most vulgar of 'modes of escaping from the consideration of the effect of social and moral influences on the human mind'. ${ }^{62}$ The historian Henry Buckle (1821-1862) picked up this thread

\footnotetext{
${ }^{57} \mathrm{D}=$ Dark brown hair, $\mathrm{N}=$ Black or intense brown hair (Niger), $\mathrm{R}=$ Red hair, and $\mathrm{F}=$ Fair hair [J. Beddoe (1885) The Races of Britain: A Contribution to the Ethnology of Western Europe (Bristol and London), p. 4].

${ }^{58}$ Beddoe, Races of Britain, p. 269, n.

${ }^{59}$ Beddoe, Races of Britain, p. v.

${ }^{60}$ B. Disraeli (1847) Tancred:, or, The New Crusade (3 vols., London), I, p. 303.

${ }^{61}$ Knox, Races, p. 26

62 J.S. Mill (1848: 1909) Principles of Political Economy with some of their Applications to Social Philosophy, $7^{\text {th }}$ edn (2 vols., London) II, p. 9.
} 
in the 1850s: 'the simple fact being, that the Irish are unwilling to work, not because they are Celts, but because their work is badly paid'. ${ }^{63}$

In many ways the Irish are a special case in the history of Britain, and anti-Irish prejudice existed for more than half a millennium before the Irish were deemed to be Celtic. To Hume the Irish were an exception in the entirety of Europe; whereas Viking invasions by 'northern tribes...had spread barbarism in other parts of Europe', they had 'tended rather to improve the Irish'. ${ }^{64}$ Jacobitism was a concurrent danger, but though Celtic Highlanders were briefly deemed a threat and their customs proscribed after the 'Forty-five', they were quickly reconciled to the Union - largely through service to the empire - and were not held in the same negative esteem as the Irish, as indeed none of the other Celts were. ${ }^{65}$ Charles Trevelyan (1807-1886), chief conductor of British governmental policy during the famine of 1846-1851, provides a revealing example. Of Cornish extraction, Trevelyan declared himself a 'reformed Celt', boasting that he 'always regarded with peculiar interest the Celtic branch of our national family. However superior the German race may be in some points, I would not have Ireland Anglo-Saxon if I could' ${ }^{66}$ For Thomas Babington Macaulay (18001859), the historical problem of the Anglo-Saxon conquest of Ireland had been masked by problems of religion that surfaced after the Reformation, for which he was criticised by Knox. ${ }^{67}$ In 1866 the North Wales Chronicle posed the question, 'Is "Fenianism" essentially Celtic?' The answer was a resounding 'no': 'The Irishman, we repeat, is not a rebel because he is a Celt, but solely because he is a Papist', ${ }^{68}$ a sentiment highlighting the religious cleavages that could still cut through any emphasis placed on ethnicity. But for the Catholic Lord Acton (1834-1902), race was the problem in the Irish situation as 'Celts are not among the progressive, initiative races'. ${ }^{69}$ T.H. Huxley (1825-1895) perceptively diagnosed the real essence of the Celtic problem:

\footnotetext{
${ }^{63}$ cited in A. Desmond and J. Moore (2009) Darwin's Sacred Cause: Race, Slavery and the Quest for Human Origins (London), p. 304.

${ }^{64}$ Hume, History of England, I, p. 328.

${ }^{65}$ See, e.g. A. Mackillop (2000) 'More Fruitful than the Soil': Army, Empire and the Scottish Highlands, 1715-1815 (East Linton).

${ }^{66}$ Cited in C. Hall (2012) Macaulay and Son: Architects of Imperial Britain (New Haven), p. 188.

${ }^{67}$ Knox, Races, p. 54.

${ }^{68}$ North Wales Chronicle, 15 December, 1866.

${ }^{69}$ J.E.E. Dalberg-Acton (1907) 'Goldwin Smith's Irish History', in J.N. Figgis and R.V. Laurence (eds.), The History of Freedom and Other Essays (London), p. 240.
} 
A leading article on the affairs of Ireland in any popular English paper is pretty certain to contain some allusions to the Celt and his assumed peculiarities. If the writer means to be civil, the Celt is taken to be a charming person, full of wit and vivacity and kindliness... or if the instructor of the public is angry he talks of the Celt as if he were a kind of savage. ${ }^{70}$

Irishness tainted the Celt, not vice versa. Irish commentators, like the Young Irelander Thomas D'Arcy McGee (1825-1868), placed varying emphasis on Celtic ideas. In response to an 1851 article in the London press, McGee drew on the historical importance of the Celts as 'the original inhabitants of Europe': figures like 'Cicero, Montesquieu, Cervantes, Ariosto, Raphael and Michael Angelo' were all Celts but 'with the $O$ at the wrong end of their name'. ${ }^{71} \mathrm{He}$ vacillated between racial essentialism - arguing all Irish were Celts and all Celts Catholic - and a more muted cultural approach wherein the Celtic element had been diluted through intermarriage with other races. ${ }^{72}$

The mixture of races was a prominent theme for Matthew Arnold, titan of Victorian cultural criticism, who staged a famous defence of the Celt in the context of his crusade against Saxon philistinism, with his lectures on 'Celtic literature' given at Oxford in 1865-66. The eldest son of 'that Teuton of Teutons, the Celt-hating Dr. Arnold', ${ }^{73}$ Matthew Arnold reacted strongly against his father's views and wrote to his sister, Jane Martha Arnold-Forster (1821-1899), of his pride in their 'semi-celtic origin', which he thought gave them the ability 'of comprehending the nature of both races'. ${ }^{74}$ Written against the background of the simmering Fenian conflict in Ireland, Arnold - who drew heavily on Ernest Renan's (1823-1892) essay on Celtic poetry and literature ${ }^{75}$ - urged his 'brother Saxons' to take a more sympathetic view of the Celtic Irish and the situation in Ireland, and called for 'a new Englishman', who

\footnotetext{
70 'Professor Huxley on Political Ethnology', Pall Mall Gazette, 10 January 1870.

71 'VINDICAE CELTICAE', The Nation, 08 March 1851.

72 D.A. Wilson (2008) Thomas D'Arcy McGee: Volume I, Passion, Reason and Politics 1825-1857 (2 vols., London), I, pp. 28-30.

73 'Folk-lore: Myths and Tales of Various Peoples', London Quarterly Review 31 (Oct., 1868), 45-85.

74 Their mother was Cornish, C.Y. Lang (1996-2001) The letters of Matthew Arnold, (2 vols., London), I, p. 515.

${ }^{75}$ E. Renan, (1854) 'La Poésie des races celtiques', Revue des deux mondes, VI, 473-506.
} 
mixed the stolidity of the Saxon with the spirit of the Celt. ${ }^{76}$ As soon as the lectures began to be printed in The Cornhill Magazine, The Times declared them to be 'arrant nonsense'. ${ }^{77}$ Others were more tolerant. The Scot Robert Giffen (1837-1910), in The Fortnightly Review, found the 'positive value...very great', particularly Arnold's popularisation of the science behind origins, though the 'Celtic fibre' in English literature was doubted. ${ }^{78}$ The Spectator praised Celtic Literature, proclaiming it Arnold's most successful attack yet on Anglo-Saxon Philistinism, as it provided a solution and was not simply destructive. ${ }^{79}$ By lending the weight and credibility of his name, Arnold forced positive Celtic ideas into mainstream debate, subverting the moralising language normally employed against the Celts by arguing that the Celtic element in the British population could do much to 'improve' the Saxon. Arnold's intervention further underscores the different ways the discursive struggle over the Celts could function as a proxy for debates about British culture and more generally.

Racial ideas developed considerably over the course of the nineteenth century; but, much like the ambiguity of the Celtic past allowed the Celt's malleability in the eighteenth century, the constantly evolving racial sciences and differences of opinion among intellectuals as to what exactly race was, meant that Celtic plasticity was preserved in the nineteenth century. Though the idea of a distinctive Celtic race was prominent, the boundaries of understanding were much more fluid than historiography has presented them to be.

Pan-Celticism is one of the most overlooked aspects of the bundle of Celtic ideas. ${ }^{80}$ Based on the premise that modern Celts share a common descent and should recognise their kinship and organise on that basis, Pan-Celticism seeks explicitly to connect the different nations of the Isles, with the exception of England, the AngloSaxon pariah. ${ }^{81}$ Pan-Celticism also serves as an example of how racial thinking re-

\footnotetext{
${ }^{76}$ See, e.g., M. Arnold (1867) On the Study of Celtic Literature, p. xi, p. xviii, p. 14.

77 The letter was printed in the introduction of Celtic Literature, where Arnold refuted it at length, Celtic Literature, pp. ix-xii.

${ }^{78}$ R. Giffen (1867) 'On the Study of Celtic Literature', Fortnightly Review, 125-6.

79 'Mr. Arnold on the Celtic Genius', The Spectator (June 22, 1867), 696-8.

${ }^{80}$ I follow Philip O'Leary in designating the institutionalised variety 'Upper Case P' Pan-Celticism, and the informal corollary, 'low case p' pan-Celticism [See P. O'Leary (1994) The Prose Literature of the Gaelic Revival, 1881-1921 (University Park, PA.), pp.375-94.

${ }^{81}$ Though Cornwall is included.
} 
invigorated ideas of the Celts in the nineteenth century: the Celtic nations were no longer just groups of people sharing a common descent, they were united by the deeper biological layer of race. Racial thinking could therefore be beneficial to modern Celts, and was not simply a scientifically justified 'othering' mechanism of English hegemony. ${ }^{82}$ Informal pan-Celtic exchanges occurred throughout the second half of the nineteenth century before the birth of the Dublin-based Celtic Association in 1900, the first institutionalisation of the Pan-Celtic principle. In the logic of nineteenth century racially-centred nationalisms, Pan-Celticism seemed to offer the possibility for the smaller nations to unite and oppose European global empires while ostensibly preserving national sovereignty - though in practice it was little more than a language-focused cultural revivalist movement.

Vague notions of Celtic kinship existed from the early-modern period but, as we have seen, the Celtic descent was squabbled over more than it was celebrated as a pannational unifier. Pan-Celticism surfaced in the nineteenth century with the rise of nationalisms across Europe. It first manifested as informal exchanges of delegates to national festivals, beginning with the Abergavenny Eisteddfod of 1838, which hosted Breton scholars and revivalists. ${ }^{83}$ Literary studies also began to take on a pan-Celtic, comparative aspect. Ernest Renan's 'La Poésie des Races celtiques' was one of the first major analyses of Celtic literature as a whole, connecting the native poetry of Brittany, Ireland, Wales and the Highlands, and treating their inhabitants as part of the same feminine Celtic race. ${ }^{84}$ Matthew Arnold built on this sentiment with On the Study of Celtic Literature in 1867, which appeared in print the same year as the first Congrès Celtique International was held in St. Brieuc. ${ }^{85}$ Organised by Charles de Gaulle (1837-1880), the uncle of the famous statesman, who in 1864 published a panCeltic appeal to 'The Celts of the Nineteenth Century', the congress aimed 'to reconnect the members of the Celtic family', and brought together a handful of Welsh and Bretons. $^{86}$

Occurring alongside some of the initial Celtic cultural forays, land agitation

\footnotetext{
${ }^{82}$ Cf. Chapman, The Celts.

${ }^{83}$ S.S. de Beaurepas (1903) Rénovation Celtique (2 vols., Paris), I, p. 5.

${ }^{84}$ Thomas Price submitted essays to the Abergavenny Eisteddfodau on these topics, but they received nowhere near the amount of attention as Renan's essay.

${ }^{85}$ Congrès celtique international, tenu à Saint-Brieuc (Côtes-du-Nord), Bretagne, en octobre 1867 (Saint-Brieuc, 1868).

${ }^{86}$ Congrès celtique, vi.
} 
stimulated early pan-Celticism. The 'Land Wars' in Ireland, along with unrest in the Highlands and discontent with landlords in Wales, served as the backdrop for organisation. ${ }^{87}$ The militant Highland cultural nationalist John Murdoch (1818-1903) wrote in 1875 that the purpose of his newspaper The Highlander was 'sinking the differences between the different members of the Celtic family' ${ }^{88}$ His ideas were cited at the Highland Land Conference of 1886 at Bonar Bridge, where John StuartGlennie (1841-1910) floated the prospect of a 'Celtic League', received with acclaim by the Irish and Welsh delegates. Glennie's main point followed a Celtic historicist line - that Celtic rights to the land had been violated in the Celtic nations by oppressive Anglo-Saxon conceptions of right and wrong. Although framing the problem as Celt against Sasannach, Glennie urged cooperation with oppressed English peasants, taking issue with Anglo-Saxon, rather than English, institutions. Michael Davitt (1846-1906), radical leader of the Irish land league, took a harder line, describing the land problem as 'seven generations' of oppression by 'AngloSaxons' ${ }^{89}$ He toured Ireland, Scotland and Wales in the 1880 s urging solidarity, but though some prominent liberals like T.E. Ellis (1859-1899) in Wales supported the idea of co-operation, it would be another fourteen years before Pan-Celticism was institutionalised. However, in the individual nations themselves, cultural nationalist movements arising out of the land agitation were successful in securing legislation on a Celtic historicist basis. William Gladstone (1809-1898) recorded reading W.F. Skene's (1809-1892) Celtic Scotland (1876-80) - a work that stressed the Celtic elements of medieval Scotland - and justified his various land acts on a historicist reading of the situation, writing to William Vernon Harcourt (1827-1904) that Highland crofters deserved legislation to restore historical rights of which they had been deprived. ${ }^{90}$

The last several decades of the nineteenth century also saw an increasing pan-Celtic element in the various national cultural festivals. Of all the gatherings, the Welsh Eisteddfod, a bardic festival and musical competition, had the longest genealogy, supposedly dating back to 540 before being re-invented in the later Middle Ages and

\footnotetext{
${ }^{87}$ D.W. Howell (2013) 'The Land Question in nineteenth-century Wales, Ireland and Scotland: a comparative study', Agricultural History Review, LXI, 83-110.

${ }^{88}$ The Highlander, 15 May 1875.

${ }^{89}$ M. Davitt (1904) The Fall of Feudalism in Ireland, or The Story of the Land League Revolution (London), xiii.

${ }^{90}$ H.G.C. Matthew (1968-94) The Gladstone Diaries (14 vols., Oxford), IX, p. 136; XI, p. 279.
} 
then again in $1789 .{ }^{91}$ Eisteddfodau were (and still are) convened by the Gorsedd, a neo-druidic body of bards invented by the stonemason Iolo Morganwg (1747-1826). The Gorsedd occasionally conferred honorary membership upon other leading Celts, and the Eisteddfod became the template for Celtic gatherings in all the Celtic nations, including the Breton Congrès Celtique in 1867, the Scottish Mòd in 1893, and the Irish Oireachtas and Feis Ceoil in 1897. Perhaps because they could point to longer lines of national tradition - though with much invention to be sure - the Welsh were more insular than the other Celtic nations, leaving the Irish to take up the Pan-Celtic banner. At the 1898 national Feis Ceoil in Belfast the delegates from the largest Celtic nations decided to form a Pan-Celtic committee, with the aim of hosting a Pan-Celtic Congress in $1900 .^{92}$

The committee renamed itself the Celtic Association in 1900, and was driven largely by the Honorary Secretary, E.E. Fournier d'Albe (1868-1933), an English-born physicist. Fournier edited the monthly journal Celtia and organised the triennial PanCeltic Congresses in Dublin (1901), Carnaervon (1904), and Edinburgh (1907). Fournier aimed at the 'regeneration of the Celtic race' through language revivals in each of the Celtic nations, which would lead to an awakening of the collective Celtic soul, and ultimately spiritual and political independence. In slightly more direct terms, Fournier characterised the approach as 'militant Celticism, directed mainly against the deadening and demoralising influences of modern Anglo-Saxondom, and working to raise the self-respect and strengthen the cohesion of the Celtic race'. ${ }^{93}$ Fournier proposed a radical political option, wherein the 'Celtic federation' would be joined by other oppressed countries in a 'Hansa of small nations' that could oppose imperial powers, above all England. But tensions between the Celtic nations still existed and, frustrated by lack of Pan-Celtic progress generally and particularly in the Highlands, Fournier at one point declared the 'sole remedy' was for Ireland to annex the Highlands: 'Scotia Minor must again become part of Scotia Major'. ${ }^{94}$ A 'Gaelic Empire', shorn of Wales 'who feebly struggles in the dark', would be composed of

\footnotetext{
${ }^{91}$ T.R. Roberts (ed.) (1909) The Eisteddfod: A Short History of the Gorsedd of the Bards of the Isle of Britain and of the National Eisteddfod of Wales with notes on the Colwyn Bay Gorsedd Circle (Chester), pp. 27, 36.

${ }^{92}$ Letter from Fournier d'Albe to Lord Castletown, 17 June 1898, MS 35,305 (1), Lord Castletown Papers, National Library of Ireland.

${ }_{93}$ Celtia, I (1901), 15.

${ }^{94}$ Celtia, III (1903), 90.
} 
Ireland, the Highlands and the Isle of Man, as 'The Gael is the strong man of these Islands...When he comes into his full strength, he will put a thing or two in order'. ${ }^{95}$ The idea was subsequently abandoned following criticism from Scottish nationalists, but nevertheless illustrates the fact that tensions relating to Celticism in the various nations still existed even in the Pan-Celtic era. Anglo-Irish figures like W.B. Yeats (1865-1939) joined the Association, along with more politically oriented veterans such as Michael Davitt. Patrick Pearse (1879-1916) and Douglas Hyde (1860-1949) briefly joined before a row with the Gaelic movement meant they were forced to abandon it; the episode points to the essential point that, despite the existence of PanCelticism, nationalism trumped cosmopolitanism. The Association lost significant momentum when Fournier retired in 1909, though the Celtic Congresses were rekindled in 1917 and the Celtic League still hosts them to this day - but the association is now defined primarily by language and culture, rather than race.

While the Celtic Association occasionally took a hardline against the Saxons, for the most part Pan-Celticism existed happily alongside other national identities, further revealing the malleability of Celticism and the overemphasised Celt-Saxon dichotomy. Cornwall, which successfully petitioned for inclusion in the Pan-Celtic Congress of 1904, provides an obvious example - the leaders of its Celtic revival remained loyal to England despite harbouring Jacobite Legitimist beliefs. But Celtic ideas could also be used to underpin ideas of Britishness in the four nations. During the land agitation in the Highlands, commentators posited an 'Anglo-Celtic' identity, arguing for a racial mixture in which Scots and English were equal partners in the Empire. ${ }^{96}$ John Stuart Glennie adopted this line of argument, attributing Shakespeare's linguistic proclivity to bardic, Cymric blood. Unionism and loyalty to the monarchy also survived in this context - the Queen was routinely toasted in Gaelic at Highland gatherings, so Highlanders could symbolically assert their distinctiveness while swearing loyalty to the monarchy.

Irish Pan-Celticists were likewise sympathetic to the Anglo-Celtic interpretation. The poet T.W. Rolleston (1857-1920) referenced the idea to dampen calls for Home Rule. The president of the Celtic Association, Lord Castletown (1848-1937), was an open Unionist and a soldier in the British Army during the Boer War; he saw no problem in

\footnotetext{
${ }^{95}$ Celtia, III (1903), 91.

${ }^{96}$ See Celtic Magazine, V (1880), 406-10.
} 
reconciling what he saw as the sacred traditions of the Celtic race with involvement in the British Empire, referring proudly to the 'two Celts who ruled the world' in 1921, Lloyd George and 'Briand of Brittany'. ${ }^{97}$ Celtic festivals could also have a British flavour. The Scottish Mòd was quickly retitled the Royal National Mòd, as was the Royal National Eisteddfod, with King Edward VII (1841-1910) and Queen Alexandra (1844-1925) honoured as members of the Gorsedd, ${ }^{98}$ and Eisteddfodau were occasionally held in England. Edward VII presented his son George as the Prince of Wales in 1901, before this ceremony was institutionalized as the Investiture in 1911, designed to reconcile Wales and England, Celt and Saxon. ${ }^{99}$

Celtic ideas have existed in a number guises and have been employed for varying purposes in the four nations. The plurality of ideas around the Celt in the long nineteenth century is a testament to their importance, despite the fact that the Celts often served as a blank canvas on which commentators could paint their own ideas about race, nation and politics in the Isles. Investigating Celticism both holistically and in each of the four nations reveals the complex, tangled history of a set of ideas to do with ethnic descent, and its links to national ideas, character, race, and 'identity'. It guards against teleology of the type that assumes Celticism has always had a panCeltic element. Despite a vague recognition of kinship in the eighteenth century, nations sharing a Celtic descent competed more amongst each other for the Celtic mantle than they did in the nineteenth century, and even with Pan-Celtic recognition and an official movement, national loyalties still took precedence over the cosmopolitan Celtic Association.

Examination of Celtic ideas in the four nations also leads to a reassessment of the importance accorded to race and ethnicity as major components of identity in recent British history writing. Given that Celticism is the major ethnic connector among the three non-English nations, its erratic variability and lack of cohesive power

\footnotetext{
${ }^{97}$ Lord Castletown of Upper Ossory (1923) “Ego”, Random Records of Sport, Service and Travel in many lands (London), p. 219.

${ }^{98}$ In 1894 The Prince and Princess of Wales were initiated into the Gorsedd, along with the princesses Victoria and Maud, Untitled notes, Irisleabhar na Gaidhilge 5 (August 1894), 65, cited in O’Leary, Prose Literature, p. 376.

${ }^{99}$ J.S. Ellis (1998) 'Reconciling the Celt: British National Identity, Empire, and the 1911 Investiture of the Prince of Wales', Journal of British Studies, XXXVII, 391-418.
} 
undermines the importance of ethnicity in the four nations more generally. Any sense of a shared Celtic identity based on race did not come about until the latter half of the nineteenth century, and even then only in conjunction with the rise of national movements.

Celtic ideas varied depending on the nation, era and intellectual backdrop and are not simply reducible to a monolithic 'other'. Under scrutiny, modern ideas of the Celt, and especially anti-Celtic prejudice, turn out to be less about separateness or similarity and more the sliding scale of a barometer measuring contemporary intellectual or political pressures. Recent studies of the Celts fit this model more than ever - from the national myth-busting of Hugh Trevor-Roper, deconstruction of Simon James and Malcolm Chapman, or the 'identity' oriented study by Murray Pittock. Undoubtedly the Celts were frequently 'othered' and some individuals held an irrational, disproportionate animosity toward them - Pinkerton or Knox, for example - but often anti-Celtic prejudice reveals more about prevailing intellectual trends or the political situation in the Isles at the time than it does anything concrete about Celtic ideas or, indeed, those considered 'Celts' themselves. 